\title{
VIABILITY OF CALCIUM ALGINATE ENTRAPPED LACTOBACILLUS CASEI DURING CONTINUOUS LACTIC ACID PRODUCTION
}

\author{
VASANTHY ARASARATHNAM* and KANDIAH BALASUBRAMANIAM \\ Department of Biochemistry, Faculty of Medicine, University of Jaffna, Kokuvil
}

(Received: 19 September 1997 ; accepted: 03 March 2000)

\begin{abstract}
Lactobacillus casei cells harvested in log phase (20h) were entrapped in calcium alginate $\left(10.0 \mathrm{~g} \mathrm{l}^{-1}\right)$. When the beads were packed in a thermostated $\left(42^{\circ} \mathrm{C}\right)$ column $(30.0 \times 2.0 \mathrm{~cm})$, the optimum flow rate for maximum lactic acid yield $(74.0 \%)$ was $18.0 \mathrm{ml} \mathrm{h}^{-1}$. At this flow rate, the productivity obtained was $21.2 \mathrm{~g} \mathrm{l}^{-1} \mathrm{~h}^{-1}$. With increase in the flow rate, viable cells in the beads were decreased. However the cell number was more than those present initially. When different concentrations of glucose in the range of 50.0 to $250.0 \mathrm{~g} \mathrm{l}^{-1}$ was passed at $18.0 \mathrm{ml} \mathrm{h} \mathrm{h}^{-1}$, maximum lactic acid yield $(81.6 \%)$ was obtained at the concentration of $125.0 \mathrm{~g} \mathrm{l}^{-1}$. With an increase in glucose concentration from 50.0 to $100.0 \mathrm{~g} \mathrm{l}^{-1}$, the viable cells in the beads were increased and further increase in glucose concentration in the feed decreased the viable cell number. When the nutrient medium containing $125.0 \mathrm{~g} \mathrm{l}^{-1}$ glucose was passed continuously, steady state was observed after 3 days and continued for 16 days. The viable cell number in the beads was constant for 16 days.
\end{abstract}

Key Word: Flow rate, immobilization, lactic acid, Lactobacillus casei, viable cell count.

\section{INTRODUCTION}

Lactic acid production from bacteria is more attractive than chemical methods. One of the major hindrances with the fermentation technique is product inhibition with decrease in $\mathrm{pH}^{1-3}$. In conventional methods, lactic acid was removed from the fermentation broth as calcium lactate ${ }^{4}$. Later studies revealed that use of immobilized cells $s^{5-4}$ or electrodialysis ${ }^{10-11}$ or extractive bioconversion $s^{12-13}$ reduce product inhibition with increase in productivity. However viability of the entrapped cells in different polymers is another hindrance for their use $e^{6,14-15}$. In this paper we present some studies of the viability of Lactobacillus casei entrapped in calcium alginate during continuous operations under different conditions.

\section{METHODS AND MATERIALS}

\section{Organism}

Lactobacillus casei DSM 20021

\section{Analytical methods}

Glucose and lactic acid were measured by HPLC (Shimadzu, Auto injector). Sugar Pak ${ }^{\text {Tn }}$, (Waters, Millipore, USA) stainless steel column (300 x 6.5, microparticulated

\footnotetext{
* Corresponding author
} 
silica gel) was used and the mobile phase was deionized water. Reference time for glucose was $8.6 \mathrm{~min}$. Samples collected at different time intervals were prepared for lactic acid estimation by filtering through a $0.45 \mathrm{~m} \mu$ Milipore filter. Viable cell count of the immobilized L.casei was determined by dissolving $2.0 \mathrm{~g}$ (wet weight) of entrapped cells in $30.0 \mathrm{ml}$ of $0.1 \mathrm{M}$ phosphate buffer ( $\mathrm{pH} \mathrm{6.5)}$ ) and growing the cells in MRS agar plate (MRS broth, $50.0 \mathrm{~g} \mathrm{l}^{-1}$ and agar, $20.0 \mathrm{~g}^{-1}$ ).

\section{Cultivation and harvesting of $L$. casei for immobilization.}

The inoculum was prepared in MRS broth $\left(52.0 \mathrm{~g} \mathrm{l}^{-1}, 50.0 \mathrm{ml}\right)$ at $\mathrm{pH} 6.5$ by inoculating with $100 \mu \mathrm{L}$. casei from frozen sample and incubating at $42^{\circ} \mathrm{C}$ for $14 \mathrm{~h}$ (300 rpm). Nutrient medium (2.5l) in a fermenter (working volume 5.0l) was inoculated with $2.5 \mathrm{ml}$ of inoculum and incubated at $42^{\circ} \mathrm{C}$ while mixing. The pH was maintained by titrating with sterile $8 \mathrm{~N} \mathrm{NaOH}$. Nutrient medium at pH 6.5 contained the following in $g l^{-1}$, glucose 150.0 , yeast extract, $10.0 ; \mathrm{K}_{2} \mathrm{HPO}_{4}, 0.5$; $\mathrm{KH}_{2} \mathrm{PO}_{4}, 0.5$ and sodium citrate, 1.0 and salt solution, $1.0 \mathrm{ml}$. The salt solution contained in $\mathrm{gl}^{-1} \mathrm{MgSO}_{4} \cdot 7 \mathrm{H}_{2} \mathrm{O}, 50.0 ; \mathrm{MnSO}_{4} \cdot \mathrm{H}_{2} \mathrm{O}, 3.1 ; \mathrm{Fe} \mathrm{SO}_{4} .7 \mathrm{H}_{2} \mathrm{O}, 2.0$ and ascorbic acid, 5.0. L casei cells were harvesced at $20 \mathrm{~h}$ by centrifuging $(12000 \mathrm{rpm})$ in a refrigerated centrifuge at $10^{\circ} \mathrm{C}$ for $15 \mathrm{~min}$. Cells washed three times with saline were used for immobilization. L. casei harvested at $20 \mathrm{~h}$ (in log phase for immobilization had the optical density of $12.8(620 \mathrm{~nm})$, dry weight of $6.9 \mathrm{~g} \mathrm{l}^{-1}$ and the viable cell count of $9.0 \times 10^{10}$.

\section{Immobilization of L. casei}

L. casei cells $(10.0 \mathrm{~g}$ wet weight) suspended in $30.0 \mathrm{ml}$ of sterile sodium alginate solution ( $\left.10.0 \mathrm{~g} \mathrm{l}^{-1}\right)$ were extruded by syringe through a needle $(0.7 \mathrm{~mm}$ diameter $)$ into $10.0 \%(\mathrm{w} / \mathrm{w})$ glucose $-0.05 \mathrm{M} \mathrm{CaCl}_{2}(1.0 \mathrm{l})$ solution and the beads were left in the solution for $2.0 \mathrm{~h}$. Beads were washed with $0.05 \mathrm{M}$ maleate $-0.05 \mathrm{M} \mathrm{CaCl}_{2}$ buffer $(\mathrm{pH}$ 6.5). Immobilized cells in the beads were incubated with nutrient medium for $72 \mathrm{~h}$ and washed with sterile $0.05 \mathrm{M} \mathrm{CaCl}_{2}$ solution. Beads were packed in a jacketed column $(30.0 \times 2.0 \mathrm{~cm})$ for further studies. Temperature of the column was maintained by circulating hot water from a water bath at $42^{\circ} \mathrm{C}$.

\section{Optimization of conditions for continuous lactic acid production}

Effect of flow rate: Nutrient medium was pumped at flow rates ranging from 6.0 to $36.0 \mathrm{~m}] \mathrm{h}^{-1}$ into the column. For each flow rate the column was repacked with freshly entrapped cells. Residual glucose and lactic acid in the spent medium were estimated. Viable cells in the beads were determined.

Effect of glucose concentration: Nutrient medium containing varying concentration of glucose (from 50.0 to $250.0 \mathrm{~g} \mathrm{l}^{-1}$ ) was pumped at optimum flow rate into the column. ${ }^{2}$ The experiment was continued as above. 
Continuous fermentation of glucose to lactic acid: Nutrient medium containing optimized amount of glucose was pumped into the column at the optimum flow rate. Fractions were collected at different time intervals and analysed for lactic acid.

\section{RESULTS}

\section{Optimum conditions for continuous lactic acid production}

Glucose was completely fermented when the flow rate was increased up to $12.0 \mathrm{ml} \mathrm{h} \mathrm{h}^{-1}$. But lactic acid yield has decreased with an increase in flow rate (Figures 1 and 2). Lactic acid productivity was increased from 8.8 to $21 \mathrm{gl}^{-1} \mathrm{~h}^{-1}$ when the flow rate was increased from 6.0 to $24.0 \mathrm{ml} \mathrm{h}^{-1}$. Viable cells entrapped in the beads before passing the medium was $23.0 \times 10^{7}$ cells $\mathrm{g}^{-1}$ wet bead. With an increase in flow rate from 6.0 to $36.0 \mathrm{ml} \mathrm{h}^{-1}$ the viable cell count in the bead was higher than what was present initially (Figure 1). Even though the productivity $\left(21.5 \mathrm{~g} \mathrm{l}^{-1} \mathrm{~h}^{-1}\right)$ was highest at the flow rate of $24.0 \mathrm{ml} \mathrm{h}^{-1}, 18.0 \mathrm{ml} \mathrm{h}^{-1}$ was selected (where the productivity was $21.2 \mathrm{~g} \mathrm{l}^{-1} \mathrm{~h}^{-1}$ ), because at this flow rate lactic acid formed was about $18.0 \%$ more than that at $20.0 \mathrm{ml} \mathrm{h}^{-1}$.

Optimum concentration of glucose for maximum lactic acid production was $125 \mathrm{~g} \mathrm{l}^{-1}$ at the optimum flow rate $\left(18.0 \mathrm{ml} \mathrm{h}^{-1}\right.$, Figure 3$)$. When the glucose concentration was increased from 50.0 to $250.0 \mathrm{~g} \mathrm{l}^{-1}$, maximum productivity of $22.3 \mathrm{~g} \mathrm{l}^{-1} \mathrm{~h}^{-1}$ was obtained at the glucose concentration of $150.0 \mathrm{~g} \mathrm{l}^{-1}$ (Figure 4). Above $125 \mathrm{~g} \mathrm{l}^{-1}$ glucose in the medium, the residual glucose also increased (Figure 3 ). The viable cell count in the freshly entrapped beads was $23.0 \times 10^{7} \mathrm{cells}^{-1}$ wet bead. With increase in glucose concentration, proliferation of the cells has taken place and the cell number has increased up to $91.8 \times 10^{13}$ while the glucose concentration was $100.0 \mathrm{~g}^{-1}$. But with further increase of glucose concentration, the cell multiplication has decreased (Figure.3).

\section{Continuous fermentation of glucose by immobilized L. casei}

The steady state of lactic acid production was observed after 3 days and was continued for 16 days without problem. But after the $17^{\text {th }}$ day, lactic acid production started to decline. The cell number in the beads showed increase in number initially but after the third day the increase was not significant with an increase in the cell leakage into the medium. However by the $10^{\text {th }}$ day it was observed that the cell leakage was pronounced and the disintergration of the beads had started. By the $26^{\text {th }}$ day leakage of the cells was obvious due to breaking of the beads. The process was terminated by the $32^{\text {nd }}$ day (Figure 5 ). 


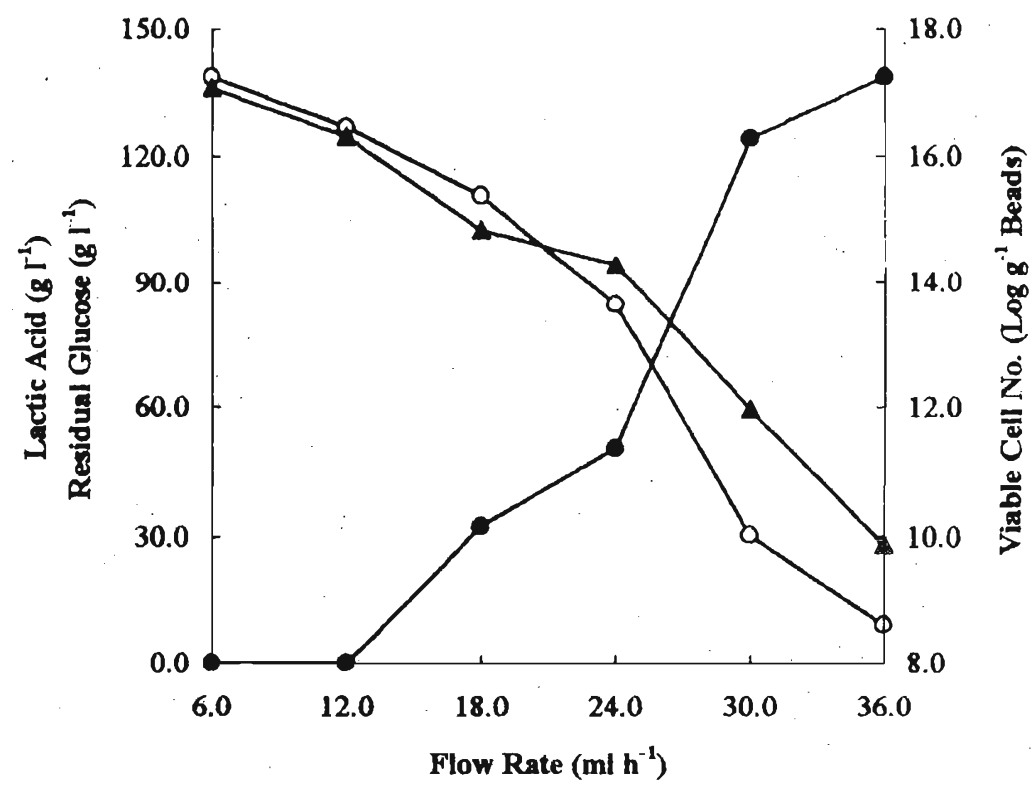

Figure 1: Effect of flow rate on ( $O$ ) lactic acid production and ( $C$ ) residual glucose in the medium and $(\Delta)$ viable cells in the beads when nutrient medium was passed at $\mathrm{pH} 6.5$ and $42^{\circ} \mathrm{C}$ into a column packed with calciumn alginate entrapped Lactobacillus casei.

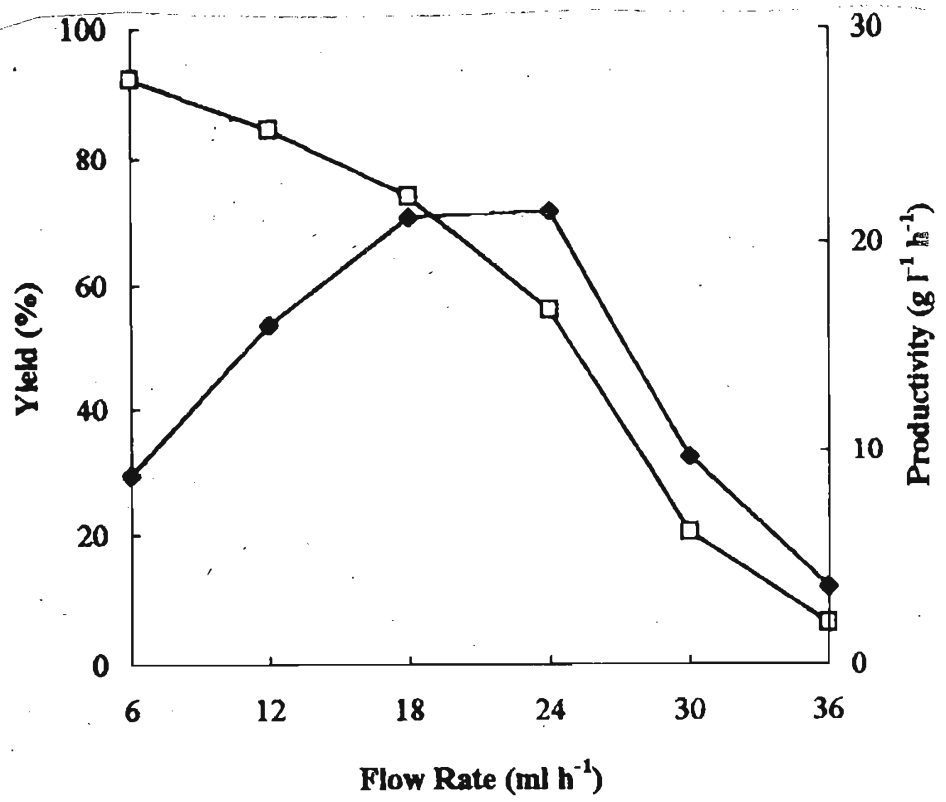

Figure 2: Effect of flow rate on lactic acid ( $\square$ ) yield and ( $\square$ ) productivity when nutrient medium was passed at $\mathrm{pH} 6.5$ and $42^{\circ} \mathrm{C}$ into a column packed with calcium alginate entrapped Lactobacillus casei. 


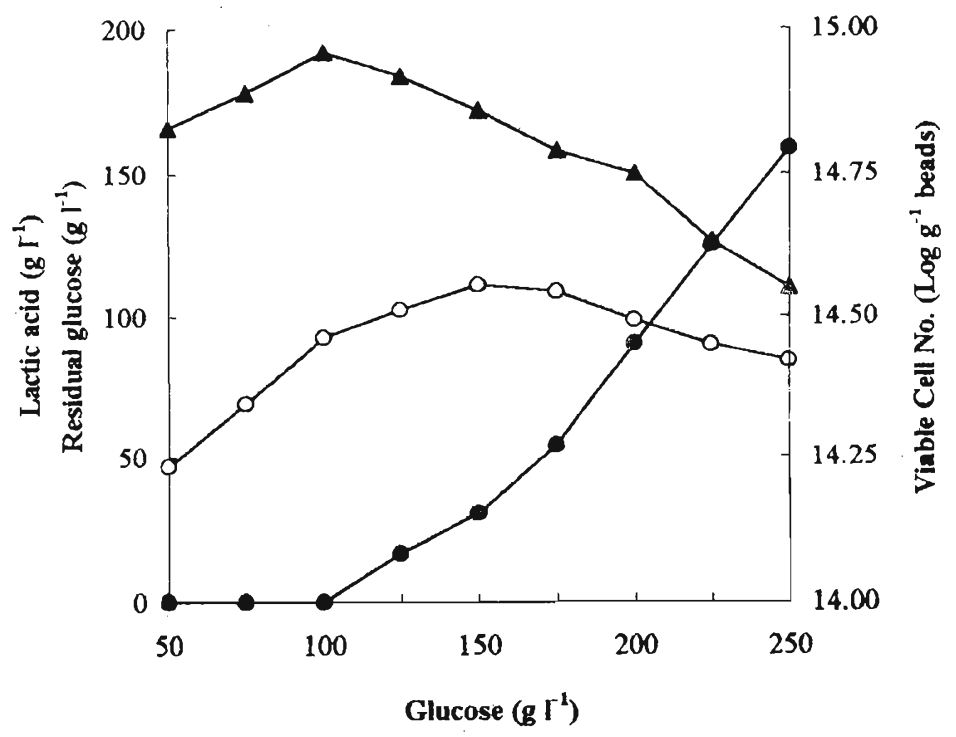

Figure 3: Effect of glucose concentration in nutrient medium on ( $O$ ) lactic acid production, ( ) residual glucose in the medium and ( $)$ viable cells in the beads when nutrient medium was passed at optimum flow rate $\left(18.0 \mathrm{ml} \mathrm{h}^{-1}\right), \mathrm{pH} 6.5$ and $42^{\circ} \mathrm{C}$ into a column packed with calcium alginate entrapped Lactobacillus casei.

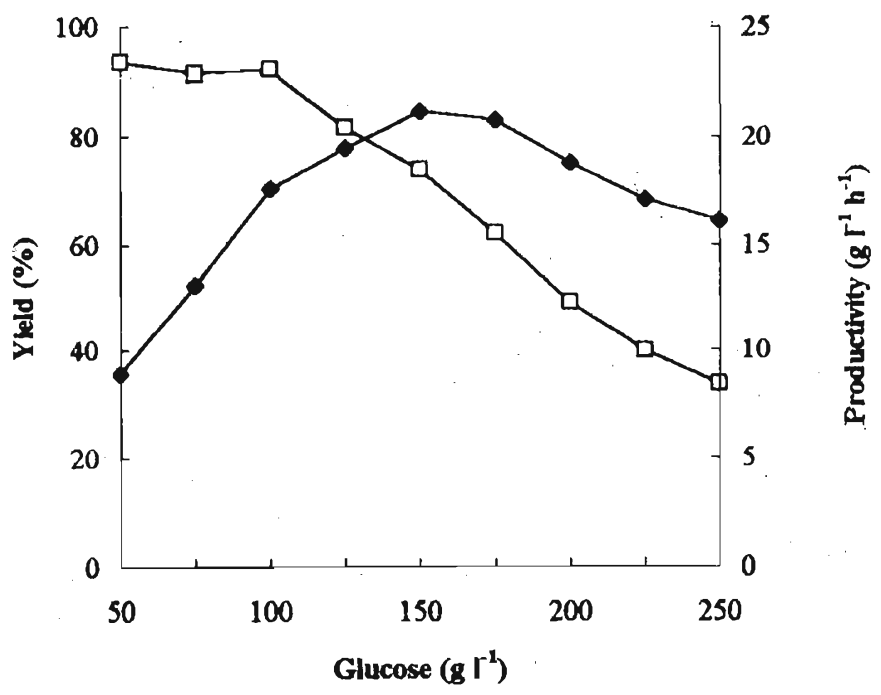

Figure 4: Effect of glucose concentration present in nutrient medium on lactic acid ( $\square$ ) yield and ( productivity when nutrient medium was fed at $18.0 \mathrm{ml} \mathrm{h}^{-1} . \mathrm{pH} 6.5$ and $42^{\circ} \mathrm{C}$ into a column packed with calcium alginate entrapped Lactobacillus casei. 


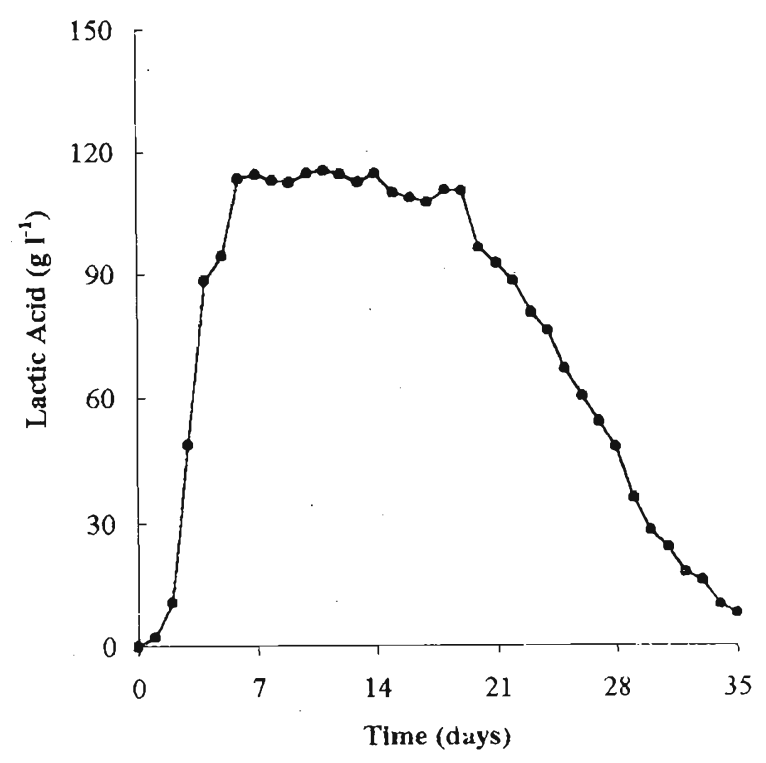

Figure 5: Continuous lactic acid production by calcium alginate entrapped Lactobacillus casei when nutrient medium containing $125 \mathrm{~g} \mathrm{l}^{-1}$ glucose was fed at $18.0 \mathrm{ml} \mathrm{h}^{-1}$ in to the column, pH 6.5 and $42^{\circ} \mathrm{C}$.

\section{DISCUSSION}

The increase in flow rate decreased glucose consumption. Reduction in lactic acid yield was due to the reduction in contact time between the cells and the substrate and leakage of the cells from the beads. Boyaval and Goulet ${ }^{16}$ have reported that the decalcification of the calcium alginate by lactic acid was pronounced at low dilution rates and the level of the leakage of the cells was also high in such cases. Thus, it is better to change to a flow rate, which gives higher productivity and product yield to avoid decalcification of the calcium alginate beads. Lactobacillus helveticus entrapped in $k$-carrageenan-locust bean gum gel at a dilution rate of $1.21 \mathrm{~h} \mathrm{~h}^{-1}$ gave a productivity of $28.5 \mathrm{~g} \mathrm{~J}^{-1} \mathrm{~h}^{-1}{ }^{17}$, which is comparable to our results. The viable cell count in the immobilized preparation was increased even when the flow rate was increased. Thus the cell multiplication more than compensated for the cell leakage. This also indicated that the sodium alginate did not show toxicity to L. casei. However the inhibitory effect of free chitosan was demonstrated for lactic acid bacteria growth. ${ }^{14-15}$

Increase in glucose concentration beyond $100.0 \mathrm{~g}^{-1}$ has decreased the cell multiplication. This is due to the osmotic effect of high sugar concentration and lactic acid inhibition on cell metabolism. ${ }^{1}$ Diffusional limitations for the substrate and product in the microenvironment would have been prominent with increased cell number in the beads. All these factors would have contributed to the decreased cell viability with increased glucose concentration. 
The main defect in our experiment was that in the feed medium no calcium was included. ${ }^{18-19}$ Calcium ions which stabilize calcium alginate would have been taken away by lactate ions produced during fermentation. ${ }^{20}$ Wada et al. ${ }^{21}$ have reported the weakening of the gel network during growth of the cells. L. helveticus entrapped in calcium alginate has shown a productivity of $8.0 \mathrm{~g} \mathrm{l}^{-1} \mathrm{~h}^{-1}$ with $50 \%$ conversion of lactose $\left(5.0 \mathrm{~g}^{-1}\right)$ where the flow rate of the substrate was $400 \mathrm{ml} \mathrm{h} \mathrm{h}^{-1}$. After a week's operation, clogging in the packed bed was observed. ${ }^{17}$ Stenroos et al. ${ }^{22}$ reported that calcium alginate entrapped $L$. delbrueckii has yielded $97.0 \%$ of lactic acid and the biocatalyst with a half life of 50.0 days. In our experiment the lactic acid yield was $92.0 \%$. In the experiment of Stenroos et al. ${ }^{22}$ the steady state was reached after one week and in our case it was faster ( 3 days). With $L$. bulgaricus immobilized in calcium alginate, 50-60\% lactic acid was obtained and the process continued for 25 days while reaching the steady state after 10 days. ${ }^{24}$ In $k$-carrageenan- locust bean gum gel beads four different strains of mesophilic lactic acid bacteria were entrapped and the productivities were high for eight weeks. ${ }^{25}$ However microscopic observation showed a progressive destruction of the beads and release of viable cells from peripheral cavities of the gels. ${ }^{25}$

L. casei cells entrapped in calcium alginate yielded maximum lactic acid at $18.0 \mathrm{ml} \mathrm{h} \mathrm{h}^{-1}$ flow rate with a productivity of $21.2 \mathrm{~g} \mathrm{l}^{-1} \mathrm{~h}^{-1}$. With increase in the flow rate, viable cells in the beads were decreased. However the cell number was more than those present initially. Maximum lactic acid yield ( $81.6 \%$ ) was obtained at the glucose concentration of $125.0 \mathrm{~g} \mathrm{l}^{-1}$. The viable cells in the beads increased with increase in glucose concentration. When the nutrient medium containing $125 \mathrm{~g} \mathrm{l}^{-1}$ glucose was passed continuously, steady state was reached after 3 days and continued for 16 days and the viable cell number in the beads was constant for 16 days.

\section{Acknowledgement}

Financial support of International Science Programs, Sweden is acknowledged.

\section{References}

1. Bibal B., Vayssier Y., Tournou M. \& Pareilleix A. (1989). Enhanced inhibitory effect of lactic acid on growth kinetics of Streptococcus cremoris during nutritional medium limitations. Applied Microbiology and Biotechnology 30: $630-635$.

2. Aeschlimann A. \& von Stockar U. (1989). The production of lactic acid from whey permeate by Lactobacillus helveticus. Biotechnology Letters 11(3): 195-200. 
3. Giraud E., Leiong B. \& Raimbault M. (1991). Influence of pH and initial lactate concentration on the growth of Lactobacillus plantarum. Applied Microbiology and Biotechnology 36: 96-99.

4. Hang Y.D. (1989). Direct fermentation of corn to $\mathrm{L}(+)$-lactic acid by Rhizopus oryzae. Biotechnology Letters 11(4): 299-300.

5. Hjorleifsdottir S., Seevaratnam S., Holst O. \& Mattiasson B. (1990). Effects of complete cell recycling on product formation by Lactobacillus casei ssp. rhamnosus in continuous cultures. Current Microbiology 20: 287-292.

6. Tuli A., Sethi R.P., Khanna P.K. \& Marwaha S.S (1985). Lactic acid production from whey permeate by immobilized Lactobacillus casei. Enzyme Microbial Technology 7: 164-168.

7. Roy T.B.V., Blanch H.W. \& Wilke C.R. (1982). Lactic acid production by Lactobacillus delbrueckii in a hollow fiber fermenter. Biotechnology Letters 4(8): 483-488.

8. Roy T.B.V., Mandel D.K., Dea D.K., Blanch H.W. \& Wilke C.R. (1983). The application of cell recycle to continuous fermentative lactic acid production. Biotechnology Letters 5(10): 665-670.

9. Guoqiang D., Kaul R. \& Mattiassin B (1992). Immobilization of Lactobacillus casei to ceramic material pretreated with polyethylenimine. Applied Microbiology and Biotechnology 37: 305-310.

10. Nomura Y., Iwahara M. \& Hongo M. (1987). Lactic acid production by electrodialysis fermentation using immobilized growing cells. Biotechnology and Bioengineering 30: 788-793.

11. de Raucourt A., Girard D., Prigent Y. \& Boyaval. P. (1989). Lactose continuous fermentation with cells recycled by ultrafiltration and lactate separation by electrodialysis, modeling and simulation. Applied Microbiology and Biotechnology 30: 521-527.

12. Seevaratnam S., Holst O., Horleifsdottir S. \& Matiasson B. (1991). Extractive bioconversion for lactic acid production using solid sorbent and organic solvent. Bioprocess Engineering 6: 35-41.

13. Yabannavar V.M. \& Wang D.I.C. (1991). Extractive fermentation for lactic acid production. Biotechnology and Bioengineering 37: 1095-1100. 
14. Groboillot A.F., Chanpagne C.P., Darling G.D., Poncelet D. \& Neufeld R.J. (1993). Membrane formation by interfacial cross-linking of chitosan for microencapsulation of Lactobacillus lactis. Biotechnology and Bioengineering.42: 1157-1163.

15. Norton S., Lacroix C., Vuillem \& J.-C. (1994). Kinetic study of continuous whey permiate fermetation by immobilized Lactobacillus helveticus for lactic acid production. Enzyme Microbial Technology 16:457-466.

16. Popper L. \& Knorr D. (1990). Application of high-pressure homogenization for good preservation. Food Technology 44: 84-89

17. Boyaval P. \& Goulet J. (1988). Optimaï conditions for production of lactic acid from cheese whey permeate by calcium alginate entrapped Lactobacillus helveticus. Enzyme Microbial Technology 10: 725-728.

18. Arasaratnam V. (1994). Nutrients along with calcium in glucose feed enhance the life of alginate entrapped yeast cells. Process Biochemistry 29: $253-256$.

19. Tipayang P. \& Kozaki M. (1982). Lactic acid production by a new Lactobacillus sp., Lactobacillus vaccinostercus Kozaki and Okada sp. nov., immobilized in calcium alginate. Journal of Fermentation. Technology 60(6): 595 -598.

20. Audet P., Paquin C. \& Lacroix C. (1988). Immobilized growing lactic acid bacteria with k-carrageenan-locust bean gum gel. Applied Microbiology and Biotechnology 29: 11-18.

21. Wada M.J. \& Chibata J. (1979). A new immobilization of microbial cells: Immobilized growing cells using carrageenan gel and their properties. Eur. Journal of Applied Microbiology and Biotechnology 8: 241-247.

22. Stenroos S.L., Linko Y.Y. \& Linko P. (1982). Production of L-lactic acid with immobilized Lactobacilus delbruekii. Biotechnology Letters 4(3): 159-164.

23. Stenroos S.L., Linko Y.Y., Linko P., Harju M. \& Heikonen M. (1982). Lactic acid fermentation with immobilized Lactobacillus sp. In: Enzyme Engineering. (Ed. Chibata I., Fukui S. \& Wingard L.B.Jr.), Vol. 6, pp 299-309, Plenum Press, New York.

24. Sodini I., Boquien C.Y., Corrieu G. \& Lacroix C. (1997). Microbial dynamics of co-and separately entrapped mixed cultures of mesophilic lactic acid bacteria during the continuous prefermentation of milk. Applied Microbiology and Biotechnology 20: 381-388. 